University of Nebraska - Lincoln

DigitalCommons@University of Nebraska - Lincoln

Publications from USDA-ARS / UNL Faculty

U.S. Department of Agriculture: Agricultural

Research Service, Lincoln, Nebraska

2011

The effects of diet on herbivory by a predaceous lady beetle

Jonathan G. Lundgren

USDA-ARS, jonathan.lundgren@ars.usda.gov

Susan E. Moser

USDA-ARS

Richard L. Hellmich

USDA-ARS

Michael P. Seagraves

USDA-ARS

Follow this and additional works at: https://digitalcommons.unl.edu/usdaarsfacpub

Lundgren, Jonathan G.; Moser, Susan E.; Hellmich, Richard L.; and Seagraves, Michael P., "The effects of diet on herbivory by a predaceous lady beetle" (2011). Publications from USDA-ARS / UNL Faculty. 1573. https://digitalcommons.unl.edu/usdaarsfacpub/1573

This Article is brought to you for free and open access by the U.S. Department of Agriculture: Agricultural Research Service, Lincoln, Nebraska at DigitalCommons@University of Nebraska - Lincoln. It has been accepted for inclusion in Publications from USDA-ARS / UNL Faculty by an authorized administrator of DigitalCommons@University of Nebraska - Lincoln. 


\title{
The effects of diet on herbivory by a predaceous lady beetle
}

\author{
Jonathan G. Lundgren $^{\mathrm{a} *}$, Susan E. Moser ${ }^{\mathrm{b}, 1}$, Richard L. Hellmich ${ }^{\mathrm{b}}$ and \\ Michael P. Seagraves ${ }^{a, 2}$ \\ ${ }^{a}$ USDA-ARS, North Central Agricultural Research Laboratory, Brookings SD 57006, USA; \\ ${ }^{b}$ USDA-ARS, Corn Insects and Crop Genetics Research Unit, Ames, IA 50011, USA
}

(Received 30 June 2010; returned 3 September 2010; accepted 14 September 2010)

\begin{abstract}
We hypothesize that herbivory by predators is affected by the complexity of their diet. Coleomegilla maculata larvae fed prey - Acyrthosiphon pisum or Ostrinia nubilalis eggs - consumed two to three times more plant tissue (pinto beans) than those fed a mixed diet (containing pollen substitute and prey-based components). Simple, prey-only diets appear to lack plant-based nutrients important to this predator.
\end{abstract}

Keywords: Coccinellidae; Coleomegilla maculata; facultative phytophagy; nutrition; predation; omnivory

Many coccinellids consume fungi, pollen, nectar, and plant tissue in addition to arthropod prey (Lundgren 2009a). These non-prey foods seldom support successful development and reproduction in coccinellids (Evans, Stevenson, and Richards 1999; Berkvens et al. 2008), and it is often erroneously concluded that they serve only to sustain predators until prey become available (Lundgren 2009b). It is important to recognize that these non-prey foods contain different nutrients from prey, and predators fed mixed diets often have higher fitness than those fed simple prey-only diets (Lundgren 2009a). Under field conditions predaceous coccinellids regularly consume non-prey foods even when prey are widely available, indicating that these foods may help to complement prey-only diets (Triltsch 1999; Weber and Lundgren 2009; Berkvens et al. 2010; Davidson and Evans 2010). Coleomegilla maculata DeGeer and Harmonia axyridis Pallas (Coleoptera: Coccinellidae), both relatively polyphagous species, consume foliage of maize (Zea mays L.) under laboratory conditions (Moser, Harwood, and Obrycki 2008; Moser and Obrycki 2009). Here, we test the hypothesis that $C$. maculata is more likely to consume plant tissue when they are reared on prey-only diets than when they are fed mixed diets.

Coleomegilla maculata adults originated in Beltsville, $\mathrm{MD}$, and were reared continuously for more than five generations. Neonates were randomly assigned to one of three dietary treatments (housed in 4-cm diameter plastic Petri dishes), that received (1) excess Acyrthosiphon pisum (Harris) (Hemiptera: Aphididae) $(n=32),(2)$ egg masses of Ostrinia nubilalis Hübner (Lepidoptera: Crambidae) $(n=34)$, or (3) Lundgren's Super C MAC Diet $(n=35)$. Acyrthosiphon pisum were reared on Pisum

\footnotetext{
*Corresponding author. Email: Jonathan.Lundgren@ars.usda.gov

${ }^{1}$ Present address: Pioneer Hi-Bred, a DuPont Business, Johnston, IA 50131, USA.

${ }^{2}$ Present address: Driscoll Strawberry Associates, Watsonville, CA 95077, USA.
} 
sativum L. Ostrinia nubilalis egg masses were produced by the USDA-ARS laboratory in Ames, IA and were frozen until use. Lundgren's Super C MAC Diet consists by volume of five parts Bee-Pro ${ }^{\circledR}$ pollen substitute (Mann Lake Ltd, MN, USA), three parts tropical fish flakes (TetraColor ${ }^{\mathrm{TM}}$ tropical fish flakes, Tetra Holding Inc., Blacksburg, VA, USA), three parts cichlid pellets (Omega One cichlid pellets, OmegaSea, Ltd, Sitka, AK, USA), three parts sun-dried Gammarus pulex (L.) (Amphipoda: Gammaridae) (Tetra BabyShrimp, Tetra Holding Inc.), and two parts Ephestia kuehniella eggs (Beneficial Insectary, Redding, CA, USA). All components (aside from the eggs) were pulverized prior to mixing the diet. Larvae received water as a saturated cotton wick. Diet was changed daily, and Petri dishes were replaced every $48 \mathrm{~h}$. Rearing conditions were $28^{\circ} \mathrm{C}, 16 \mathrm{~h} \mathrm{~L}: 8 \mathrm{~h} \mathrm{D}$ photoperiod and approximately $40 \%$ relative humidity.

Survival and the duration of each larval stadium were recorded for each individual daily for $9 \mathrm{~d}$. At this point larvae were weighed and transferred to plant tissue with forceps. Pinto beans (Phaseolus vulgaris L.) were grown to the two-leaf stage under controlled environmental conditions $\left(24 \pm 0.1^{\circ} \mathrm{C}, 16 \mathrm{~h} \mathrm{~L}: 8 \mathrm{~h} \mathrm{D}, 75 \% \mathrm{RH}\right)$ in a potting mix (Sungro Sunshine SB300 Universal Professional Growing Mix; Sungro Horticultural Products, Bellevue, WA, USA) and were watered daily for approximately $14 \mathrm{~d}$. Plants were removed from the soil, and soil was washed from the root mass prior to inserting it into a water-filled $50 \mathrm{ml}$ centrifuge tube covered in Parafilm. The plant and tube were then placed into a $710 \mathrm{ml}$ plastic cup with a larva, and sealed with mesh clot. After $24 \mathrm{~h}$, tissue damage from the plant was photographed using a zoom stereomicroscope (Model SMZ1000, Nikon Instruments Inc., Melville, NY, USA). The digital image files were exported to ImageJ (U.S. National Institutes of Health, Bethesda, MD, USA, http://rsb.info.nih.gov/ij/), converted to 8-bit grayscale, and the 2-D leaf area consumed by each larva was calculated.

The durations of the first, second, and third stadia were compared among treatments using ANOVA, and significantly different treatment means were separated using the LSD means separations. Mean larval mass just before they were offered the bean tissue was compared among the treatments using ANOVA and LSD means separations. The mean area of plant tissue consumed (standardized according to larval size) was compared among the treatments using Kruskal-Wallis nonparametric ANOVA, and significantly different means were separated using K-W ANOVA pairwise comparisons. Statistics were run on Systat 11 (Systat Software Inc., Chicago, IL, USA).

Although all were of high quality, the three diets tested supported larval development to different degrees. First instars fed diet developed significantly faster than those fed eggs, and aphid-fed first instars developed at a significantly distinct intermediate rate $\left(F_{2,95}=6.60, P=0.002\right)$. Aphid-fed second instars developed significantly faster than egg-fed second instars, and those fed diet had a significantly distinct intermediate developmental rate $\left(F_{2,94}=3.11, P=0.049\right)$. Diet-fed third instars developed significantly more slowly than the prey fed treatments, which were statistically similar $\left(F_{2}, 58=14.22, P<0.001\right)$. The result of these differences in growth rates is that 87,67 , and $67 \%$ of aphid-, diet-, and egg-fed treatments were $4^{\text {th }}$ instars at the end of the experiment. Larvae reared on diet, aphids, and eggs weighed a mean (SEM) of $8.14 \pm 0.54,7.72 \pm 0.34$, and $5.86 \pm 0.31 \mathrm{mg}$ each $\left(F_{2,95}=8.82\right.$, $P<0.001)$. Arthropod prey vary widely in their suitability for developing predators 


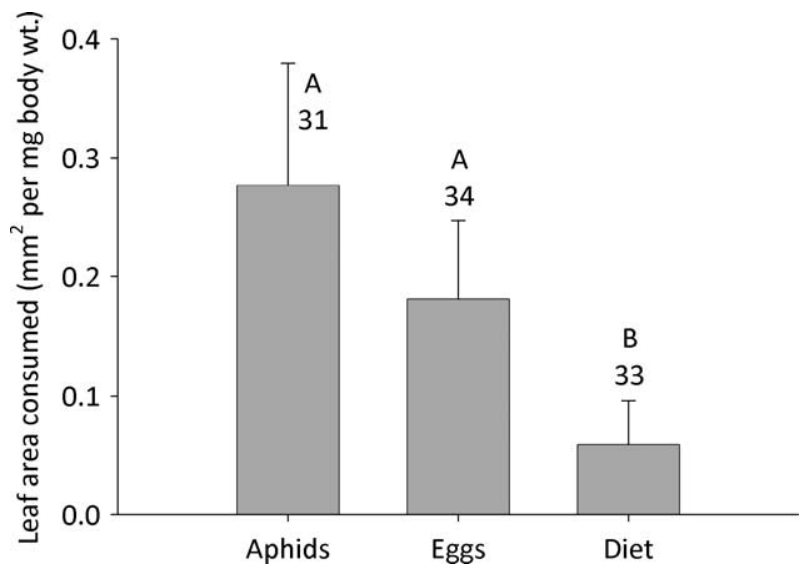

Figure 1. The mean $( \pm$ SEM) leaf area (standardized by body weight) consumed by Coleomegilla maculata larvae reared on aphids (Acyrthosiphon pisum), eggs (Ostrinia nubilalis), or a mixed diet containing prey and non-prey components. Numbers above the bars refer to sample sizes, and bars capped with different letters refer to significantly different means (nonparametric pairwise comparisons; $\alpha=0.05$ ).

(Michaud 2005; Omkar, Kumar, and Sahu 2009), and more complex (or mixed) diets are often superior to those composed of solitary components in supporting predator development and fitness (Lundgren 2009a). This is in part because the defensive characteristics and nutritional quality of prey often vary, and arthropods self-select their diets to obtain optimal nutrient ratios when given the option (Waldbauer and Friedman 1991).

The diet of C. maculata larvae affects their likelihood to consume plant tissue, and those fed prey-only diets consumed two to three times more plant material than those fed a mixed diet. Larvae reared on aphids or eggs ate significantly more plant area for their body size than those reared on the customized mixed diet (KruskalWallis $\chi^{2}=10.36, \mathrm{df}=2, P=0.006$ ) (Figure 1). The mean (SEM) area of plant tissue consumed was $1.74 \pm 0.66,1.08 \pm 0.40$ and $0.44 \pm 0.32 \mathrm{~mm}^{2}$ for aphid-, egg-, and dietfed treatments. Plant tissue may contain nutrients that are deficient in prey, and may be critical for the optimal growth and performance of predatory insects (Lundgren 2009 b). Increased consumption of plant material by prey-fed larvae is consistent with the hypothesis that plant tissue provides critical nutrition that is lacking in many simple, prey-only diets. Also, this result suggests that predator larvae compensate for this deficiency by consuming additional plant tissue. This omnivory is particularly important in light of the current use of plant-incorporated insecticides in agroecosystems, which may inadvertently expose plant-feeding predators to toxins.

\section{Acknowledgements}

We thank Keith Bidne for assisting in data collection and Kurt Rosentrater for advice on image analysis. Don Weber provided C. maculata to begin our culture, Louis Hesler supplied the aphids, and Jean Dyer supplied the O. nubilalis eggs for use in this study. Louis Hesler, John Obrycki and Don Weber provided helpful comments on an earlier draft of this manuscript. Mention of any proprietary products does not constitute endorsement by the USDA. 


\section{References}

Berkvens, N., Bonte, J., Berkvens, D., Deforce, K., Tirry, L., and De Clercq, P. (2008), 'Pollen as an Alternative Food for Harmonia axyridis', BioControl, 53, 201-210.

Berkvens, N., Landuyt, C., Deforce, K., Berkvens, D., Tirry, L., and De Clercq, P. (2010), 'Alternative Foods for the Multicoloured Asian Lady Beetle Harmonia axyridis (Coleoptera: Coccinellidae)', European Journal of Entomology, 107, 189-195.

Davidson, L.N., and Evans, E.W. (2010), 'Frass Analysis of Diets of Aphidophagous Lady Beetles (Coleoptera: Coccinellidae) in Utah Alfalfa Fields', Environmental Entomology, 39, 576-582.

Evans, E.W., Stevenson, A.T., and Richards, D.R. (1999), 'Essential Versus Alternative Foods of Insect Predators: Benefits of a Mixed Diet', Oecologia, 121, 107-112.

Lundgren, J.G. (2009a), 'Nutritional Aspects of Non-prey Foods in the Life Histories of Predaceous Coccinellidae', Biological Control, 51, 294-305.

Lundgren, J.G. (2009b), Relationships of Natural Enemies and Non-prey Foods, Dordrecht, The Netherlands: Springer International.

Michaud, J.P. (2005), 'On the Assessment of Prey Suitability in Aphidophagous Coccinellidae', European Journal of Entomology, 102, 385-390.

Moser, S.E., and Obrycki, J.J. (2009), 'Non-target Effects of Neonicotinoid Seed Treatments; Mortality of Coccinellid Larvae Related to Zoophytophagy', Biological Control, 51, 487492.

Moser, S.E., Harwood, J.D., and Obrycki, J.J. (2008), 'Larval Feeding on Bt Hybrid and NonBt Corn Seedlings by Harmonia axyridis (Coleoptera: Coccinellidae) and Coleomegilla maculata (Coleoptera: Coccinellidae)', Environmental Entomology, 37, 525-533.

Omkar, Kumar, K., and Sahu, J. (2009), 'Performance of a Predatory Ladybird Beetle, Anegleis cardoni (Coleoptera: Coccinellidae) on Three Aphid Species', European Journal of Entomology, 106, 565-572.

Triltsch, H. (1999), 'Food Remains in the Guts of Coccinella septempunctata (Coleoptera: Coccinellidae) Adults and Larvae', European Journal of Entomology, 96, 355-364.

Waldbauer, G.P., and Friedman, S. (1991), 'Self-selection of Optimal Diets by Insects', Annual Review of Entomology, 36, 43-63.

Weber, D.C., and Lundgren, J.G. (2009), 'Assessing the Trophic Ecology of the Coccinellidae: Their Roles as Predators and Prey', Biological Control, 51, 199-214. 